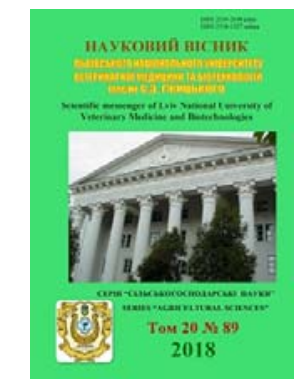

Науковий вісник Дьвівського національного університету ветеринарної медицини та біотехнологій імені С.3. Гжицького

\author{
Scientific Messenger of Lviv National University \\ of Veterinary Medicine and Biotechnologies
}

UDC $636.22 / 28.6 / 2$

\title{
Productive and technological qualities of Simmental cows depending on the index of general activity
}

\author{
N.M. Hordiichuk, B.S. Denkovich, L.M. Hordiichuk \\ Stepan Gzhytskyi National University of Veterinary Medicine and Biotechnologies Lviv, Ukraine
}

Article info

Received 06.09.2018 Received in revised form 11.10.2018 Accepted 12.10.2018

Stepan Gzhytskyi National University of Veterinary Medicine and Biotechnologies Lviv, Pekarska Str., 50, Lviv, 79010, Ukraine. Tel.: +38-067-366-30-49 E-mail: natalijgordiychuk@gmail.com

Hordiichuk, N.M., Denkovich, B.S., \& Hordiichuk, L.M. (2018). Productive and technological qualities of Simmental cows depending on the index of general activity. Scientific Messenger of Lviv National University of Veterinary Medicine and Biotechnologies, 20(89), 75-78. doi: $10.32718 /$ nvlvet8914

With the introduction of intensive technologies, requirements that need to be taken into account when selecting animals for industrial production of livestock products are increasing. At the same time pay attention to the adaptability of animals to maintain large groups, the leveling of animals by productivity, the need for feed, and others. However, due regard is not paid to ethical indicators. In turn, the accounting of ethological indicators in the selection contributes to a more complete realization of the genetic potential of animals in the process of their livelihoods. In this regard, the practical application of scientifically grounded methods, taking into account the behavior of animals for the formation of herds of cows, capable of exhibiting high milk productivity in specific technological conditions, becomes of special significance. Formation of milk production of Simmental breed cows depends on the indicators of the rhythmic manifestation of behavioral reactions. It was established that the highest tastes, the content of fat and protein and their yields in milk were characterized by the firstborns, classified by the index of general activity to the group of active (4992 kg, 3.84\%, 3.38\%, 191.7 and $168.7 \mathrm{~kg}$ respectively) and ultraactive (respectively $4763 \mathrm{~kg}, 3.81 \%, 3.35 \%, 181.5 \mathrm{~kg}$ and $159.6 \mathrm{~kg}$ ). Cows classified by the index of general activity as infrapassive and passive had significantly lower rates for their analogues of the active class, respectively: by their hopes - by 456 and $333 \mathrm{~kg}$, by the fat content - by 0.02 and $0.04 \%$, by the protein -0.06 and $0.09 \%$, the milk fat content - 18.4 and $14.7 \mathrm{~kg}$, and protein - by 18.1 and $15.4 \%$. Since the lowest productivity was observed in the cows of the group, they are infra-passive and passive, then the task is early detection and removal of animals with a low index of total activity index. Cows of different ethological groups differ significantly among themselves according to technological signs of udder. Animals of the active class are best adapted to machine milking. Calculations of the economic efficiency of milk production of cows of different ethological groups have shown that the use of ethological indicators in the formation of a dairy herd can reveal cows, capable of producing a much larger quantity of milk of high quality, while reducing the costs of its production.

Key words: cow, behavior, activity, milk production, flint, efficiency.

\section{Продуктивні й технологічні якості симентальських корів залежно від індексу загальної активності}

\author{
Н.М. Гордійчук, Б.С. Денькович, Л.М. Гордійчук
}

Львівський національний університет ветеринарної медицини та біотехнологій імені С.3. Гжицького, м. Львів, Україна

У статті наведено результати досліджень впливу поведінки корів-первісток симентальської породи для формування стада, здатного на високу молочну продуктивність в умовах промислової технологї виробництва молока. Дослідження проведені в племзаводі фермерського господарства “Пчани-Денькович” Жидачівського району Львівської області на коровах-первістках симентальської породи. Встановлено, щзо найвищими надоями, вмістом жиру, білка і їхніми виходами в молоці та придатністю до машинного доӥння характеризувалися корови, які належали за індексом загальної активності до групи класу активних. Оскільки найменша продуктивність спостерігалась у корів групи інфрапасивні $i$ пасивні, то завданням є раннє виявлення $і$ вибракування тварин з низьким показником індексу загальної активності. Розрахунки економічної ефективності виробництва молока корів 
різних етологічних груп показали, щео використання етологічних показників при формуванні молочного стада дозволяє виявити корів, здатних продукувати значно більшу кількість молока високої якості, знижуючи при цฺьому затрати на його виробництво.

Ключові слова: корова, поведінка, активність, виробництво молока, вим'я, ефективність.

Вступ

Із впровадженням інтенсивних технологій зростають вимоги, які необхідно враховувати при доборі тварин для промислового виробництва продукції тваринництва. При цьому звертають увагу на пристосованість тварин до утримання великими групами, вирівняністю тварин за продуктивністю, потребою в кормах та ін. Однак не приділяється належної уваги етологічним показникам. Своєю чергою облік етологічних показників при доборі сприяє більш повній реалізації генетичного потенціалу тварин в процесі їхньої життєдіяльності (Judin, 2002; Zubets, 2010; Popova, 2015; Gordiychuk et al., 2016; Shevchuk, 2017).

У зв'язку з цим особливого значення набуває практичне застосування науково-обгрунтованих методик, з урахуванням поведінки тварин для формування стад корів, здатних виявляти високу молочну продуктивність в конкретних технологічних умовах (Velikjanin, 2000; Ljubimov and Batanov, 2002; Kramarenko et al., 2017).

3 огляду на вищезазначене метою наших досліджень було вивчити поведінку корів-первісток симентальської породи для формування стада, здатного на високу молочну продуктивність в умовах промислової технології виробництва молока.

Таблиця 1

Розподіл корів за групами активності

\section{Матеріал та методи досліджень}

Дослідження проводили в племзаводі фермерського господарства “Пчани-Денькович” Жидачівського району Львівської області на коровах-первістках симентальської породи.

Піддослідні корови за методикою В.І. Великжанина (Velikjanin, 2000) були поділені залежно від індексу загальної активності на чотири групи: I - інфрапасивні, II - пасивні, III - активні і IV - ультраактивні (табл. 1). Індекс загальної активності визначали відношенням часу затраченого коровою на реалізацію елементарних актів поведінки за весь період спостереження до загального часу спостереження за нею. Був проведений хронометраж поведінки 3 використанням абетки елементів поведінки корови для отримання найповніших даних про ритмічність прояву поведінкових реакцій.

Всі матеріали хронометражних спостережень опрацьовано методами варіаційної статистики за Г.Ф. Лакіним (Lakin, 1990).

\section{Результати та їх обговорення}

Із результатів досліджень встановлено, що серед 38 піддослідних корів більшість належали залежно від індексу загальної активності, до групи активних $34,2 \%$ та ультраактивних - 28,9\%, а частка інфрапасивних і пасивних становила відповідно 15,8 та $21,1 \%$ (табл. 1). Величина нормованого індексу загальної активності варіює в інтервалі від 0 до 1.

\begin{tabular}{lccc}
\hline \multicolumn{1}{c}{ Групи корів } & $\begin{array}{c}\text { Кількість корів, } \\
\text { голів }\end{array}$ & $\begin{array}{c}\text { Межа класових проміжків вели- } \\
\text { чини нормованого індексу зага- } \\
\text { льної активності }\end{array}$ & $\begin{array}{c}\text { Середнє значення } \\
\text { 3 похибкою }\end{array}$ \\
\hline I - інфрапасивні & 6 & $0-0,696$ & $0,658 \pm 0,0041$ \\
II - пасивні & 8 & $0-0,697-0,737$ & $0,726 \pm 0,0032$ \\
III - активні & 13 & $0,738-0,778$ & $0,759 \pm 0,0043$ \\
IV - ультраактивні & 11 & $0,779-1$ & $0,845 \pm 0,0091$ \\
\hline
\end{tabular}

Нами встановлено, що формування молочної продуктивності корів симентальської породи залежить і від показників ритмічності прояву поведінкових реакцій (рис. 1). Так, найвища молочна продуктивність була у корів-первісток, зарахованих залежно від індексу загальної активності до групи активні та становила 4992 кг, що на 10,1\% більше, ніж у корів першої групи, зарахованих до групи інфрапасивні, відповідно від корів другої і четвертої групи - на 7,1 та 4,8\%.

За вмістом жиру в молоці істотної різниці між групами не виявлено, однак за даним показником незначна перевага належить коровам 3 третьої групи зарахованих залежно від індексу загальної активності до групи активні (3,84\% проти 3,80\% у групі пасивних ровесниць).

За вмістом загального білка в молоці також переважали корови, які належали, зважаючи на індекс загальної активності, до групи активних (3,38\% проти 3,29\% у групі пасивних).

Вихід молочного жиру і білка в молоці найвищим був у первісток, зарахованих за індексом загальної активності до групи активних (191,7 кг), а аналоги 3 першої групи - інфрапасивні - мали найнижчі показники (173,3 кг).

Таким чином, за молочною продуктивністю перевага належить коровам, які за індексом загальної активності віднесені до активних та ультраактивних. 

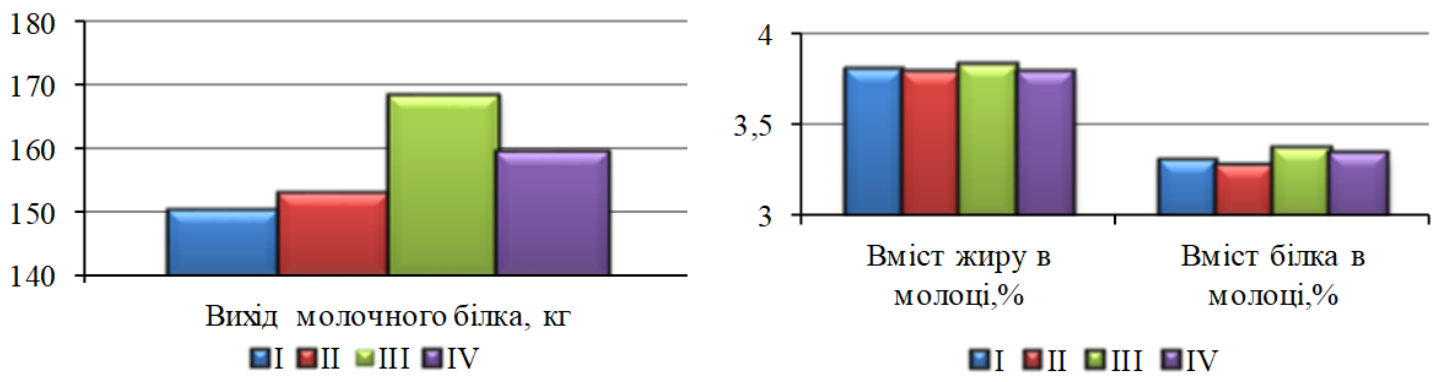

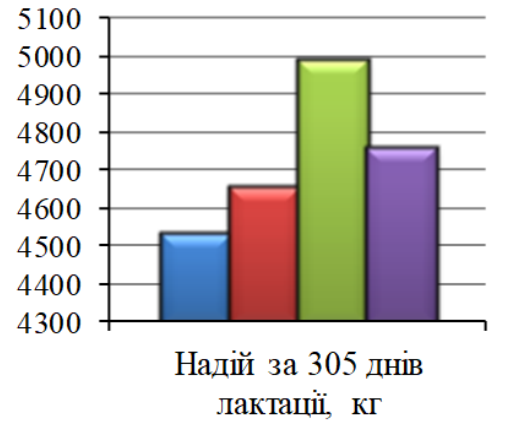

gI घII घIII घIV

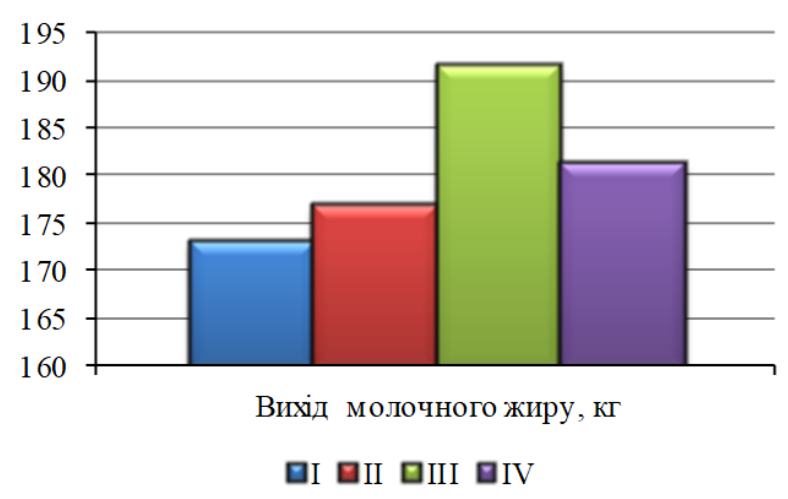

Рис. 1. Молочна продуктивність корів породи залежно від індексу загальної активності

Інтенсивна технологія виробництва молока обумовлює необхідність підвищення вимог щодо добору корів за технологічними властивостями молочної залози: формою і різноманітністю розвитку часток, інтенсивністю молоковиведення і т. д.

Обстежені корови різних етологічних груп добре пристосовані до машинного доїння (рис. 2). Так, індекс вимені у корів піддослідних груп з різними кла- сами активності був на середньому рівні $(43,6 \%$ у активних особин проти $42,4 \%$ в ультрапасивних) i різко не відрізнявся.

Швидкість молоковіддачі дещо вища у корів, віднесених за індексом загальної активності до групи активні $(1,82$ кг/хв) та була на 6,4 та $5,8 \%$ вища за показник корів групи ультраактивні та пасивні відповідно.

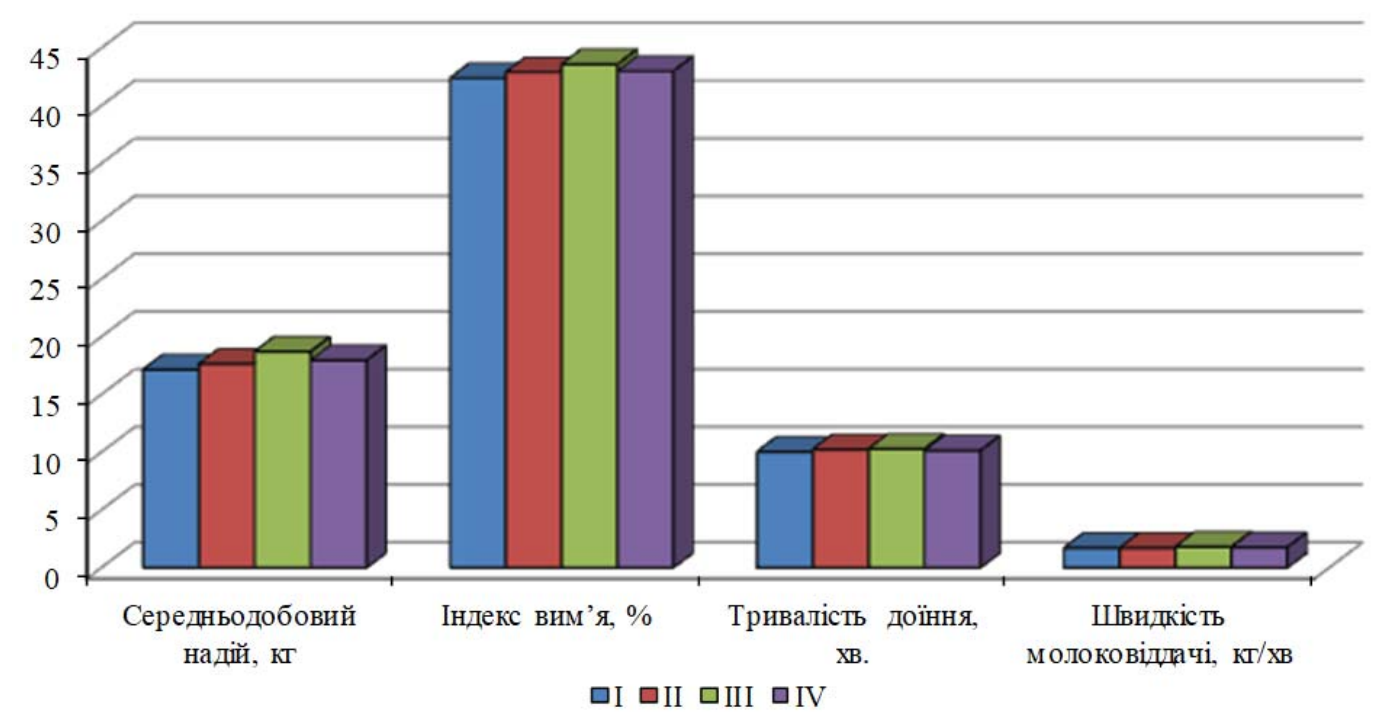

Рис. 2. Технологічні особливості вимені корів піддослідних груп

Отже, найкраще пристосовані до промислової технології виробництва молока корови, які за індексом загальної активності належать до групи класу активних.

На основі показників продуктивності нами була проведена економічна оцінка результатів досліджень, результати якої наведені в таблиці 2.
Із вищенаведених даних видно, що зі збільшенням надою молока базисної жирності в третій групі корів (5538 кг), які зраховані до класу активних, знижується собівартість 1 ц молока $(658,2$ грн проти 692,6 грн у першій групі), що при однаковій реалізаційній ціні (900 грн) вплинуло на зростання чистого доходу (241,8 грн проти 207,8 грн у першій групі) та рівня рентабельності. 
Таблиця 2

Економічна ефективність виробництва молока корів різних етологічних груп

\begin{tabular}{|c|c|c|c|c|}
\hline \multirow{2}{*}{ Показники } & \multicolumn{4}{|c|}{ Групи корів } \\
\hline & $\mathrm{I}$ & II & III & IV \\
\hline Надій за лактацію, кг & 4536 & 4659 & 4992 & 4763 \\
\hline Вміст жиру в молоці, \% & 3,82 & 3,80 & 3,84 & 3,81 \\
\hline Надій молока базисної жирності, кг & 5096 & 5207 & 5538 & 5337 \\
\hline Собівартість 1 ц молока, грн & 692,6 & 686,8 & 658,2 & 670,3 \\
\hline Реалізаційна ціна 1 ц молока, грн & \multicolumn{4}{|c|}{900} \\
\hline Чистий дохід на 1 ц молока, грн & 207,8 & 213,2 & 241,8 & 229,7 \\
\hline Рентабельність, \% & 30,0 & 31,0 & 36,7 & 34,3 \\
\hline
\end{tabular}

Найвища рентабельність була у тварин третьої групи, які в залежності від індексу загальної активності віднесені до класу активних і становила 27,7\%, що переважала тварин 3 першої, другої і четвертої груп відповідно - на 6,$4 ; 5,3$ та 2,4\%.

\section{Висновки}

Формування молочної продуктивності корів симентальської породи залежить і від показників ритмічності прояву поведінкових реакцій.

Встановлено, що найвищими надоями, вмістом жиру і білка та їхніми виходами в молоці характеризувалися первістки, віднесені за індексом загальної активності до групи активних (відповідно 4992 кг, $3,84 \%, 3,38 \%, 191,7$ та 168,7 кг) та ультраактивних (відповідно 4763 кг; 3,81\%, 3,35\%, 181,5 кг та 159,6 кг). Корови, які за індексом загальної активності відносились до інфрапасивних та пасивних, мали значно нижчі показники за своїх аналогів класу активних відповідно: за надоєм - на 456 та 333 кг, вмістом жиру - на 0,02 та $0,04 \%$, білка - 0,06 та $0,09 \%$, виходом молочного жиру - 18,4 та 14,7 кг і білка - на 18,1 та $15,4 \%$.

Оскільки найменша продуктивність спостерігалась у корів групи інфрапасивні й пасивні то завданням є раннє виявлення і вибраковка тварин з низьким показником індексу загальної активності.

Корови різних етологічних груп суттєво відрізняються між собою за технологічними ознаками вимені. Найкраще пристосовані до машинного доїння тварини, зараховані до третьої групи класу активних.

Розрахунки економічної ефективності виробництва молока корів різних етологічних груп показали, що використання етологічних показників при формуванні молочного стада дозволяє виявити корів, здатних продукувати значно більшу кількість молока високої якості, знижуючи при цьому затрати на його виробництво.

Перспективи подальших досліджень. В подальшому буде вивчено зв'язок показників ритмічності прояву поведінкових реакцій з відтворними якостями корів.

\section{References}

Gordiychuk, N.M., Gordiychuk, L.M., \& Salamakha, I.J. (2016). Behaviourof cows and calves at different ways maintenance. Scientific Messenger LNUVMBT named after S.Z. Gzhytskyj, 18, 2(67), 57-60. doi: $10.15421 /$ nvlvet6713.

Judin, M.F. (2002). Etologicheskaja harakteristika molodnjaka simmental'skoj porody. Molochnoe i mjasnoe skotovodstvo. 1, 36-39 (in Russian).

Kramarenko, S., Kuzmicheva, N., \& Kramarenko, A. (2017). Principal component analysis of the exterior traits in dairy cows. Scientific Messenger LNUVMB, 19(79), 48-52. doi:10.15421/nvlvet7910.

Lakin, G.F. (1990). Biometrija: ucheb. posob. dlja biol. spec. Vuzov. 4-e izd., pererab. i dop. M.: Vyssh. shk. (in Russian).

Ljubimov, A.I., \& Batanov, S.D. (2002). Molochnaja produktivnost' korov raznoj povedencheskoj aktivnosti. Zootehnija, 8, 21-23 (in Russian).

Popova, V. (2015). Etolohichni osoblyvosti tvaryn znamianskoho typu poliskoi miasnoi porody pry riznykh umovakh utrymannia. Naukovyi visnyk LNU veterynarnoi medytsyny ta biotekhnolohii, 17(3), 291-296. https://nvlvet.com.ua/index.php/journal/article/view/5 64 (in Ukrainian).

Shevchuk, N.P. (2017). The genesis of the ukrainian red dairy breed. Scientific Messenger LNUVMBT named after S.Z. Gzhytskyj, 19(74), 203-207. doi: $10.15421 /$ nvlvet7444.

Velikjanin, V.I. (2000). Metodicheskie rekomendatsii po ispolzovaniyu etologicheskih priznakov $\mathrm{v}$ selektsii molochnogo skota. VNII genetiki i razvedeniya selskohozyaystvennyih jivotnyih. SPb, 3-15 (in Russian).

Zubets, M.V. (2010). Etolohiia molochnoi khudoby [Tekst]: nauk.ta navch.-metod. vyd. UAAN, Natsionalnyi ahrarnyi un-t, Kharkivska zooveterynarna akademiia. Kh. (in Ukrainian). 